\title{
Exploration of College English Teaching Model in the Era of Internet Plus
}

\author{
Xue $\mathrm{Li}^{*}$ \\ School of Foreign Languages, Dalian Jiaotong University, Dalian, Liaoning 116028, China \\ *Corresponding author. Email: lixue_sherry@djtu.edu.cn
}

\begin{abstract}
With the advent of the Internet plus era, internet has become an important means for college students to acquire knowledge and exchange information, which has prompted a large-scale reform of the traditional teaching model. It is an inevitable trend in keeping with the trend of the times. As a basic course in China's education system, college English curriculum is of great significance to the popularization of English in China and the improvement of students' professional ability. At first, this paper expounds the influence of Internet on college English teaching, and then analyzes the teaching principle under background of internet plus, finally puts forward the teaching mode under the internet environment. We need to change teaching conception, update teaching methods, using micro class, Mooc, WeChat teaching methods so that the students can learn more comprehensive and practical English knowledge.
\end{abstract}

Keywords: internet plus, college English teaching, influence, teaching mode

\section{INTRODUCTION}

"Internet plus" is the result of economic and social development and the evolution of Internet technology. Nowadays, with the deep integration of network technology and information technology, Internet technology has made outstanding development in various fields. The "Internet plus" action plan has been elevated to the level of national development strategy. This measure not only brings challenges to college English teaching, but also brings opportunities for effective teaching reform. Teachers, as important medium knowledge dissemination, should update teaching ideas, and actively learn the practical skills of micro course, MOOCs, flipped classroom and independent learning platform, to make sure the teaching effect is twice the result with half the effort. At the same time, we should cultivate students good habits of autonomous learning, efficiently accomplish the teaching mission and objectives and promote the reform of college English teaching.

\section{THE INFLUENCE OF INTERNET PLUS ON COLLEGE ENGLISH TEACHING}

\subsection{Promote the Innovation and Change of Teaching Methods}

Under the background of "Internet plus", China has made great innovations in science and technology, information technology and digital technology, which have been widely used in the field of education. Traditional college
English teaching is mostly based on school-based teaching materials and is learned through teachers' explanation and motivation. Students are always in the passive learning level. Both teachers and students pay too much attention to the test results, and their proficiency in English is relatively low. However, under the background of "Internet plus" and driven by information technology, the traditional college English teaching means and methods have been greatly innovated. Through the application of Internet micro-classroom, video-sharing teaching and Internet flipped classroom teaching, college English teaching presents a diversified development trend [1]. Moreover, college English teaching is no longer limited to the content of textbooks, and English teaching is gradually freed from time and space constraints. Move to a more distant network platform. Through the digitalized teaching of college English, the efficiency of English teaching can be improved and students' English level can be improved comprehensively.

\subsection{Change the Teaching Philosophy and Learning Manner}

Nowadays, with the continuous improvement of students' comprehensive quality and learning ability, the Internet and digital technology have greatly promoted the transformation of college English teaching philosophy and students' learning methods. Students are no longer simply attached to the teacher-centered teaching model, but also through the sharing of learning resources on the Internet and the support of multimedia teaching facilities, further improve the ability of independent learning. Many students can collect relevant course resources on the network platform and digital equipment. Through effective 
preparation before class, students can learn college English courses without leaving home, while teachers can also use multimedia video teaching equipment to teach in real time. To some extent, it breaks through the time and geographical constraints of traditional college English teaching [2]. At the same time, it also improves the learning efficiency and teaching effect, which is more conducive to the construction and improvement of knowledge network in breadth and depth.

\subsection{Strengthen Communication Between Teachers and Students}

The traditional teaching methods of college English are mainly "spoon-feeding" and "didactic teaching". In the teaching process, teachers play the role of conductor and students become passive in the learning process. Under the background of "Internet plus", the network provides a communication platform for students and teachers to share resources, breaks the limitation of traditional teaching methods, and brings convenience to the learning of teachers and students. Teachers can also use the Internet platform to upload the courses they want to teach to the Internet for students to review after class. Students can download the courses through the Internet to promote the communication between teachers and students while improving the speed of information transmission. Teachers and students can expand their extracurricular knowledge through the Internet in their spare time after class.

\subsection{Optimize Learning Methods}

At present, most colleges and universities in China have begun to conduct English teaching through the Internet, and students improve their English listening, speaking, reading and writing abilities through multimedia. Some colleges and universities combine English classroom teaching with multimedia teaching, which can not only give full play to the fun of English class, but also stimulate students' interest in learning. Through Internet learning, students can not only improve their English learning enthusiasm, but also give full play to their dominant position

\section{ANALYSIS OF COLLEGE ENGLISH TEACHING PRINCIPLE UNDER THE BACKGROUND OF INTERNET PLUS}

\subsection{Establish a Student-centered and Teacher- assisted Teaching Model}

Teachers should actively change the dominant position of teachers and students in class. Teachers should put down the authority of teachers, adhere to the teaching requirements for college English courses, focus on students as the main principle, and pay attention to the whole process of students' learning. Instead of the traditional one-way teaching mode, the teaching is carried out based on the individual differences of students, so as to realize teaching according to needs and students' aptitude. In the era of "Internet plus", knowledge is equal, so is the relationship between teachers and students [3]. With the diversification of teaching methods and the diversity of students' learning approaches, teachers are no longer the dominant player in the classroom and should gradually change from a single designer of classroom teaching to a situation where teachers and students jointly develop the curriculum. Teachers play the role of developers of teaching environment and designers of teaching activities. Students should act as regulators and evaluators in the teaching process. To realize the all-round development of students, it requires the comprehensive cultivation of students' knowledge, ability and quality. Therefore, teachers' identity must be redefined, constantly improving their professionalism, and vigorously developing while protecting students' individuality.

First of all, teachers need to break the traditional teaching methods and use the Internet to innovate the teaching model. Secondly, the teacher should give the class to the students properly and play a supporting role in the teaching. The teacher should fully realize the importance of equality between teachers and students and fully reflect the openness, democracy and fairness of college English [4]. Finally, in the course of teaching, teachers should completely abandon the traditional classroom model of "one person alone in one lecture", highlight the dominant position of students, and give students sufficient time for self-study and independent thinking. Under the background of "Internet plus" English teaching, teachers should play an auxiliary role and adopt different teaching methods for students with different English ability and English foundation. For students whose English foundation is relatively weak, teachers should take improving English foundation as the principle, clarify their role in the classroom, help and guide students to learn efficiently, and cannot force students to accept difficult knowledge that their ability cannot bear. For the students who have a higher English foundation or are interested in English, we should tap their English potential and give them guidance as soon as they encounter difficulties. Set up open-up class group learning, such as group teaching, situational teaching. Teachers can make good use of the Internet to choose a short English dialogue, can be movies, songs, etc., let the students in the form of group to group dialogue, and to perform, so to strengthen the students' knowledge of English at the same time, also can exercise the students' ability of speaking and listening, making English classroom atmosphere active, promoting students' enthusiasm of learning English. 


\subsection{Train Students to Form Good Study Habits}

Under the "Internet plus" environment, mobile learning is increasingly used in college English teaching, which can free students from time and space limitations and enable them to conduct more flexible and personalized learning. Mobile learning devices mainly include smart phones, laptops, iPads and so on [5]. This kind of mobile learning is generally promoted after class, whose function is to extend classroom teaching, such as introducing background knowledge, cultural factors, language skillsat so as to better optimize the effect of college English classroom teaching. With the continuous advancement of mobile learning, students can use smart terminal devices such as mobile phones, flexibly use independent learning network APP, make full use of mobile learning advantages, and independently use online software to complete vocabulary, listening and test questions. Teachers should also pay attention to management, strengthen humanistic education, and cultivate students' correct learning attitude and consciousness while building the network independent learning platform and communication platform. Students can conduct independent learning with the help of Mooc resources, as well as vocabulary, listening and writing training through APP software, laying a good foundation for effective learning in teaching. The habit of using fragmented time for targeted learning is very beneficial to the improvement of students' comprehensive English ability and quality.

\subsection{Optimize English Learning Environment}

Colleges and universities should create a high-quality English learning environment for students to ensure the quality of English teaching. Use the Internet to create a teaching synchronization feature that enables students to learn English wherever they are. As long as there is the $\mathrm{WiFi}$, students can study for free via mobile phones or the Internet. With the continuous development and optimization of the network teaching platform, network English knowledge resources are increasingly rich. Students can find the English materials they need through the resource database, and they can also make use of the internet platform for knowledge detection to timely understand their own shortcomings. Teachers use the internet platform to transfer resources to students, so that students can better grasp English knowledge. Colleges and universities should also create a testing function board. After learning English knowledge in class, students can use this platform to test their English level and knowledge. Students learn about their own shortcomings and loopholes in the learning process through self-detection system. Then, in English class, I communicated with teachers and classmates to realize knowledge sharing in the form of discussion and communication, and transformed knowledge into ability, so as to truly improve students' English level and realize the purpose of innovative teaching.

\section{ESTABLISH BLENDED TEACHING MODEL UNDER THE BACKGOUND OF INTERNET PLUS}

\begin{abstract}
The single teaching model must be transformed. With the help of network resources, audio, pictures, videos and other materials can be integrated to bring the resonance of multi-sensory information acquisition to students, so as to carry out hierarchical and phased teaching for students, so as to promote the overall learning ability of students in the class.
\end{abstract}

\subsection{Micro-Course Teaching Mode}

Micro-course teaching mode mainly refers to that teachers carry out "teaching" and "learning" activities in the form of videos by combining teaching knowledge points and key points with other teaching resources according to new teaching curriculum standards and teaching practice purposes [6]. The teaching video time must be effectively controlled, generally around 8 minutes. The video content covers a wide range of resources, such as teaching materials, teaching tests, teachers' comments, which can be Shared with students through the network platform to create an atmosphere for students to use online teaching resources. Teachers can get students' comments, Suggestions and ideas through information feedback. As an extension of classroom teaching, it plays a positive role in improving students' autonomous ability in learning English. Combined with the teaching mode of group discussion, students can better internalize the textbook knowledge and play a complementary role. Teachers clearly marked the teaching objectives, learning priorities, learning difficulties and other parts, laying a good foundation for the follow-up flipped classroom teaching. Students can carry out targeted teaching according to teachers' guiding ideas, optimize the teaching time, and make clear the direction of students' independent learning. Students can feedback their questions to the teacher online. After the teacher has summarized the questions, they will arrange the questions on the blackboard at the specified time and tell the main questions in a unified way to help students complete their learning. Meanwhile, Homework is done to ensure students' learning effect. The interaction between teachers and students not only optimizes the college English teaching system, but also drives the development of micro-course teaching model.

\subsection{Mooc Teaching Model}

Mooc is a kind of open online course development mode, which is not widely used in China, but has the advantage of personalized training for students. Teachers build and practice Moocs on the basis of flipped classroom, which can realize the efficient combination of new and old 
teaching resources and teaching modes [7]. In addition, with abundant Mooc resources and convenient introduction of teaching, students can input and search languages according to their own needs. After obtaining online teaching resources, they can watch and complete independent learning repeatedly. Teachers can discuss the learning experience with students after class to optimize the teaching effect. Students can search for designated courses through some online course platforms, and complete independent learning through video lectures, online tests and homework assignments. The teaching arrangement and content design of teaching video resources must accord with students' knowledge base to ensure the learning effect.

\subsection{WeChat Teaching Mode}

WeChat, as the most popular social networking tool at present, is widely used among college students and has been built into a new learning support environment under the mobile Internet environment. According to its characteristics, in accordance with certain teaching rules and the traditional classroom teaching, it forms a blended learning situation and we can apply it to teaching practice. Teachers can pass lesson plans, network connections and videos through $\mathrm{WeChat}$ common communication software, so as to realize resource sharing and shorten the distance with students. At any time, I will check students' learning and know their current situation, so as to realize fragmented language teaching and learning.

\subsection{Maker Education Teaching Mode}

Maker education integrates innovative research, experiential learning, project education and other concepts, which is an education model based on practical courses [8]. The application of this mode of education in the reform of college English teaching can expose students to more abundant knowledge in the sharing process, which can not only feel the creative pleasure brought by the learning process, but also provide them with opportunities for innovative learning. This is very beneficial to the improvement of students' innovation ability, diversified thinking and flexible problem-solving ability, and can gradually achieve the educational goal of promoting the comprehensive development of students.

\section{CONCLUSION}

Under the background of "Internet plus", college English teaching mode focuses on teaching efficiency, expanding teaching knowledge and cultivating students' independent learning ability. If college English teaching wants to achieve more and more ideal teaching effect, it is necessary to apply modern information technology teaching methods to classroom and after-class teaching.
With the integration of Moocs, micro-courses and mobile learning methods, students can learn in real time and communicate with teachers online, regardless of time and region, so as to better respect students' learning subjectivity and guide students to conduct more independent, innovative and efficient learning. While taking the initiative to shorten the relationship with teachers, it improves the status of independent learning and ensures the learning effect. Therefore, college English educators need to strengthen the in-depth analysis and research on the innovation path of English teaching reform under the Internet environment, so as to guide students how to make efficient use of online teaching tools. In this way, the advantages of "Internet + " teaching can be more fully and incisively brought into play, so as to promote the better development of college English teaching and learning.

\section{REFERENCES}

[1] Hua Lulu, Chen Lin, Sun Mengmeng, Research on the Improvement of English Learning by Artificial Intelligence, Modern Distance Education, vol.6, pp.27, 2017.

[2] Michael Negnevitsky: Atificial Intelligence: A Guide to Intelligent System [M], Third Edition, Perason Education Limited, 2012.

[3] Kuaibin and He Juan, Reflections on the Communicative Approach in College English Teaching, Course Education Research, vol.37, pp. 96-97, 2016.

[4] Bruton A, Samuda V., Learner and Teacher Roles in the Treatment of Error in Group Work, RELC Journal, vol. 11, pp. 49- 63, 1980.

[5] Godwin-Jones, R.: Augmented Reality and Language Learning: From Annotated Vocabulary to Place-based Mobile Games, Language Learning \& Technology, vol. 3, pp. 9, 2016.

[6] Zhou Yun, A Study on College English Smart Teaching Model from the Perspective of Mobile Internet, Modern Educational Technology, vol. 12, pp.79-85, 2016.

[7] Cui He, Design and Research on Flipped Classroom Learning in College English Under the Background of "Internet + Education", Ability Wisdom, vol.1, pp.4, 2017.

[8] Mo Huifang, Research on the Teaching Mode of Maker Education Course Oriented by "Learning to do Creation", vol. 7, pp. 16-17, 2019. 